\title{
A potential of Telang tree (Clitoria ternatea) in human health
}

\author{
Muhammad Ezzudin, R. and *Rabeta, M.S. \\ Food Technology Division, School of Industrial Technology, Universiti Sains Malaysia, 11800 Minden, \\ Penang, Malaysia
}

\author{
Article history: \\ Received: 7 March 2018 \\ Received in revised form: 19 \\ April 2018 \\ Accepted: 26 April 2018 \\ Available Online: 9 May \\ 2018
}

\section{Keywords:}

Clitoria ternatea,

Proximate analysis,

Chemical analysis,

Biological effects

\section{DOI:}

https://doi.org/10.26656/fr.2017.2(5).073

\begin{abstract}
Clitoria ternatea (CT) or commonly known as telang tree originates from the Fabaceae family. The flower of this tree has vivid, deep-blue and white colouration and it is usually used as a natural colourant in food preparation especially in the local culinary scene such as for the preparation of nasi kerabu and kuih tekan. Moreover, this plant could act as a food source for the livestock due to the taste and nutritious value it has. Besides that, parts of the plant such as its leaves, flowers, and roots are believed to possess sought-after medicinal values such as analgesic, antipyretic and anti-inflammatory properties. The plant also possesses a number of advantages such as antioxidant, antidiabetic, antimicrobial, antihelminthic, hepaprotective and antiasthmatic properties that are beneficial and useful in reducing health disorders. For the purpose of this study, the chemical composition such as proximate analysis of flowers, leaves and also active compound were also included in the review.
\end{abstract}

\section{Introduction}

Plants have long been used to treat diseases because they contain many natural ingredients, such as phenolic compounds. Clitoria ternatea (CT), commonly known as telang (Malaysia), butterfly pea, kordofan pea (Sudan), cunha (Brazil) or pokindang (Philippines) is from the Fabaceae family. The plant is 90.00 to $162.00 \mathrm{~cm}$ tall. It is a long-lived perennial herb with an erect habit (Kalamani and Michael Gomez, 2001). Besides that, according to Gomez and Kalamani (2003), CT has solitary flowers with vivid, deep-blue and white colouration. The flowers are also 6.00 to $12.00 \mathrm{~cm}$ long. Furthermore, it also contains 6 to 8 brown or blackcoloured seeds per pod which are slightly pubescent or glabrous. Moreover, the butterfly pea is self-pollinated by nature, but it also exists because of cross-pollination due to the identification of genotype segregation (Cook et al., 2005).

The flowers of CT, or the telang flower, widely used as a natural colourant ranging from drink (Duhard et al., 1997) to food (Patras et al., 2010) industries and it is sensitive to temperature and $\mathrm{pH}$ changes. Besides that, it was used to color the nasi kerabu blue which is a famous dish in Kelantan. Usually, nasi kerabu (blue-coloured rice) is eaten with grilled chicken or fried fish coated with flour, fish crackers, salted egg and other local herbs. Many reports have been published on the medicinal effects of CTs such as antipyretic, analgesic and antiinflammatory (Mukherjee et al., 2008). These properties are good for one's health and well-being because they help to reduce health disorders. In addition, this flower is also used as a source of food for livestock. It is highly preferred by livestock because of its mild and acceptable taste over other types of legumes (Gomez and Kalamani, 2003). Therefore, the present review is aimed to compile a comprehensive review of CT plant that covers its botanical characteristics, phytochemistry and pharmacology activities particularly derived from flowers, roots and leaves extracts.

\section{Proximate and mineral analysis of Telang}

A proximate and mineral analysis of CT flowers has been reported by Neda et al. (2013). The analysis conducted on the flowers provides a strong basis for emphasizing the nutritional value of CT (Table 1 and Table 2).

Calcium is a very important form of mineral for the body because it is necessary for the formation of strong and healthy bones and teeth, blood clotting and skeletal development (Forbes, 2012). Heavy metal content such as the content of cadmium and arsenic in telang flower was below $0.0001 \mathrm{mg} / 100 \mathrm{~g}$ and did not exceed the limit set by (Codex, 1995). The limit has been set at 4.00 $\mathrm{mg} / 100 \mathrm{~g}$ and $0.05 \mathrm{mg} / 100 \mathrm{~g}$, respectively. Moreover, 
lead and nickel found in the flower was within the acceptable range with less than $0.2 \mathrm{mg} / \mathrm{kg}$ (National standard of China on Maximum Levels of Contaminants

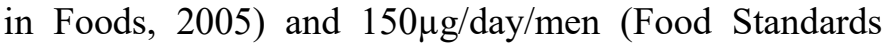
Australia New Zealand 2003), respectively.

Besides that, proximate and mineral analyses of telang leaves have been reported by Deshmukh and Jadhav (2014). This report aimed to examine nutritional composition and mineral of leaves. Fresh telang leaves contained the highest amount of moisture with $74.51 \%$. Moreover, protein constituents have been ranked second after moisture with $14.99 \%$ value. Much higher protein content in the leaves of CT could be useful to work against retardation, muscle wasting, oedema and abnormal swelling of the belly (kwashiorkor). Other significant components such as ash, crude fiber, and fat contain at $8.73 \pm 0.22 \%, 8.45 \pm 0.05 \%$ and $5.50 \pm 0.10 \%$, respectively. The least significant component of the telang leaves is the carbohydrate, which measured at only $0.08 \pm 0.00 \%$.

Table 1. Proximate analysis of Telang flower

\begin{tabular}{cc}
\hline Consitituent & Percentage (\%) \\
\hline Moisture & 92.40 \\
Ash & 0.45 \\
Fat & 2.50 \\
Protein & 0.32 \\
Crude fiber & 2.10 \\
Carbohydrate & 2.23 \\
\hline
\end{tabular}

Table 2. Mineral analysis of Telang flower

\begin{tabular}{cc}
\hline Mineral & Value $(\mathrm{mg} / \mathrm{g})$ \\
\hline Calcium & 3.10 \\
Magnesium & 2.23 \\
Potassium & 1.25 \\
\hline
\end{tabular}

\section{Chemical analysis}

The major constituents found in CT are flavonoids, anthocyanins, alkaloids, ternatins, saponins, tannins, taraxerol, and taraxerone. According to Kazuma et al. (2003), to be specific 14 types of flavonol glycosides have been identified in the CT plants by using spectroscopy. The compounds are quercetin $3-\left(2^{\mathrm{G}}-\right.$ rhamnosylrutinoside), kaempferol 3- $\left(2^{\mathrm{G}}-\right.$ rhamnosylrutinoside), kaempferol 3-neohesperidoside, quercetin 3-neohesperidoside, myricetin 3neohesperidoside, kaempferol 3-rutinoside, quercetin 3rutinoside, myricetin 3-rutinoside, kaempferol 3glucoside, quercetin 3-glucoside, myricetin 3-glucoside, kaempferol 3-O-(2"-O- $\alpha$-rhamnosyl-6"-O-malonyl)- $\beta$ glucoside, quercetin 3-O-(2"-O- $\alpha$-rhamnosyl-6"-Omalonyl)- $\beta$-glucoside and myricetin 3-O-(2"-O- $\alpha$ rhamnosyl-6"-O-malonyl)- $\quad \beta$-glucoside. $\quad$ Moreover, kaempferol 3-glucoside, quercetin 3-glucoside and myricetin 3-glucoside compounds were also identified (Slimestad et al., 1995).

\section{Biological effects}

\subsection{Antioxidant activity}

The antioxidant activity of the aqueous extractions of CT flowers showed a much higher scavenging activity compared to methanol-based extracts (Rabeta and An Nabil, 2013). Besides that, when the concentrations of extracts were increased, the percentage of the extracts to scavenge off free radicals also increased (Ramaswamy et al., 2011). This finding was supported by Rabeta and An Nabil (2013), where the concentration samples of both water and methanol were $25.00 \mu \mathrm{g} / \mathrm{mL}, 50.00 \mu \mathrm{g} / \mathrm{mL}$, $100.00 \mu \mathrm{g} / \mathrm{mL}$ and $125.00 \mu \mathrm{g} / \mathrm{mL}$ while the scavenging activity was $32.67 \pm 1.16 \%, \quad 353.33 \pm 3.06 \%$, $411.33 \pm 1.16 \%$ and $422.67 \pm 3.06 \%$, respectively in methanol.

On the other hand, the water content was $390.67 \pm 2.31 \%, \quad 401.33 \pm 3.06 \%, \quad 449.33 \pm 2.31 \% \quad$ and $490.67 \pm 4.62 \%$, respectively. In this activity, anthocyanin acts as antioxidant agents that protect the plant's cells from damage caused by high light, through the absorption of blue-green ultraviolet rays which will produce reactive oxygen species, also known as ROS (Mazza and Miniati, 1993).

\subsection{Antidiabetic activity}

A few studies have been carried out to examine and investigate the potentials of CT flowers that can be used as natural substances to reduce blood glucose level. A report by Gunjan et al. (2010) stated that the glucose level tested in diabetic rats significantly decreased after 14 days of administering with CT flower extract with $150 \mathrm{mg} / \mathrm{kg}$ body weight.

Moreover, administrations of telang flower and leaf extracts on these rats after being injected with alloxan resulted in a significantly decreased level of serum glucose, total cholesterol, triglycerides, urea, blood glucose, glycosylated haemoglobin, and creatine while serum insulin, HDL-cholesterol, protein, skeletal muscle and glycogen content level were increased (Daisy et al., 2009). In addition, the rat treated with CT flower extracts showed a positive antidiabetic activity against hyperglycaemic and hyperlipidaemic which can prevent it from liver and renal damage.

\subsection{Antimicrobial activity}

This plant is a natural product that may provide a new source of antimicrobial agents which has an 
enormous therapeutic potential to heal a significant number of infectious diseases. Examples of microorganisms that have gained resistance to antimicrobials include Staphylococcus aureus, Candida albicans, Shigella dysenteriae, Streptococcus faecalis, Salmonella enterica serovar Typhi, S. enterica serovar Enteritidis and Escherichia coli (Barbour et al., 2004).

A previous study conducted by Anand et al. (2011) reported that the methanolic and petroleum ether extracts of the CT leaves are the greatest protection against Bacillus cereus and $S$. enterica serovar Typhi, respectively, each with a larger inhibition zone. Besides that, an earlier study carried out by Shekhawat and Vijayvergia, (2010) highlighted that methanolic extraction of Clitoria ternatea showed the maximum zone of inhibition against bacterial species such as Staphylococcus aureus, Klebsiella pneumoniae, Pseudomonas aeruginosa and S. enterica serovar Typhi with zone of inhibition at $10,12,16$ and $13 \mathrm{~mm}$, respectively.

Moreover, the antifungal activity of Clitoria ternatea methanol extract also showed that maximum zone of inhibition against the fungal species such as Aspergillus niger, Penicillium chrysogenum, Aspergillus flavous and Fusarium oxiporum with inhibition zone at 10, 7, 12 and $11 \mathrm{~mm}$, respectively.

\subsection{Antihelmintic activity}

Several studies investigating the anti-helmintic activity of CT against Indian earthworms, known as Pheretima posthuma in root extracts (Khadatkar et al., 2008) and leaf extracts (Salhan et al., 2011; Sarojini et al., 2012) were carried out. Different types of solvent were used in these experiments such as petroleum ether, ethyl acetate, methanol, ethanol and other aqueous extracts with various concentrations measured at 10.00 $\mathrm{mg} / \mathrm{mL}, 25.00 \mathrm{mg} / \mathrm{mL}, 50.00 \mathrm{mg} / \mathrm{mL}$ and $100.00 \mathrm{mg} / \mathrm{mL}$. The results obtained from these studies showed that alcoholic extracts from the roots resulted in having the shortest time for the earthworm to be paralyzed at 4.27 $\min$ and dead at $10.58 \min$ using a $50.00 \mathrm{mg} / \mathrm{mL}$ concentration. Moreover, root extracts of methanol, ethyl acetate and petroleum ether showed time for the earthworms to be paralyzed was at $5.63 \mathrm{~min}, 6.28 \mathrm{~min}$ and $16.28 \mathrm{~min}$ while the time took for death to occur was at $11.92 \mathrm{~min}, 21.59 \mathrm{~min}$ and $45.92 \mathrm{~min}$, respectively (Khadatkar et al., 2008).

A positive correlation was found between the concentration of extracts and time taken for the earthworms to be paralyzed and dead. When increasing the concentration of the extracts from $10.00-100.00 \mathrm{mg} /$ $\mathrm{mL}$, the time taken for the earthworms to be paralyzed and dead were decreased (Khadatkar et al., 2008; Salhan et al., 2011; Sarojini et al., 2012). Besides that, the antihelminthic property is generally understood to mean killing the earthworms either by starving or paralyzing them due to no storage of energy to fulfill their metabolic needs. A possible explanation for this can be attributed to phenolics which contain tannins that bind and free protein in gastrointestinal tract of host animals (Athnasiadou et al., 2001) or glycoproteins on the cuticle of the parasites (Thompson and Geary, 1995) which cause damage to the mucopolysaccharides layer and lead to death (Chandrashekhar et al. 2008).

\subsection{Hepatoprotective activity}

Recently, in vitro studies have shown that CT extracts can act as a strong hepatoprotective agent against paracetamol (Nithianantham et al., 2011) and carbon tetrachloride, $\mathrm{CCl}_{4}$ (Shanmugasundaram et al., 2010) found in induced rat. According to Nithianantham et al. (2011), rats treated with CT leaf extracts showed positive results in protecting themselves against damage caused by paracetamol. Interestingly, the treated group with CT extracts was observed to possess a reduced level of enzymes such as aspartate aminotransferase (AST), alanine aminotransferase (ALT) and bilirubin compared to a raised level in AST, ALT, and bilirubin in paracetamol-treated group.

Moreover, this finding supports the findings of Shanmugasundaram et al. (2010) which highlighted that ethanol extracts of CT leaf (EECT) showed a significant hepatoprotection against carbon tetrachloride, $\mathrm{CCl}_{4}$ in induced rats. A group of rats treated with $\mathrm{CT}$ extracts experienced a significant reduction in total bilirubin, conjugated bilirubin and unconjugated bilirubin at $1.66 \pm 0.05 \mathrm{mg} / \mathrm{L} \quad 0.35 \pm 0.02 \mathrm{mg} / \mathrm{L}$ and $1.76 \pm 0.05 \mathrm{mg} / \mathrm{L}$, respectively. This result may be explained by the fact that the presence of phenolic and flavonoid compounds in CT leaf extracts has improved the regeneration ability of the liver (Shanmugasundaram et al., 2010; Nithianantham et al., 2011; Nithianantham et al., 2013).

\subsection{Antiasthmatics activity}

Several studies investigating anti-asthmatic activity were carried out on CT root extracts (Taur and Patil, 2011; Chauhan et al., 2012). In her study, Taur and Patil (2011) found that, when mice administered with a higher concentration of root extracts through injection, the total of leucocytes and eosinophilia counts decreased after 24 hours. Further analysis showed that rats which were pretreated with root extracts showed a positive result in an inhibited area of blue dye leakage with $66.51 \%$ to $71.70 \%$ of inhibition. This is largely due to antihistamine and anti-inflammatory mechanisms found in 
the root extracts.

Moreover, Chauhan et al. (2012) also found that rats treated with CT root extracts have shown a positive result in delaying the time for the appearance of preconvulsive dysponea after exposing them to histamine aerosol. The time for pre-convulsive dysponea kept increasing after these rats were treated with root extracts at the first and fourth hours with $44.20 \pm 1.07 \mathrm{~s}$ and $56.40 \pm 2.00 \mathrm{~s}$, respectively. A possible explanation for these results is due to the presence of flavonoid and saponin found in the root extracts of this CT plant.

\subsection{Neuropharmacological activity}

A considerable amount of literature has been published on improving cognitive behavior from CT root extract (Rai et al., 2001; Rai et al., 2002). In an investigation of improving learning and memory, Rai et al. (2001) found that administered with $100 \mathrm{mg} / \mathrm{kg}$ of aqueous root extract have significantly increased acetylcholine (Ach) content in hippocampus of neonatal rats from $52.79 \pm 12.36$ to $68.83 \pm 9.87 \mathrm{nmol} / \mathrm{g}$ tissue while for young adult's rats were from $33.9 \pm 6.92$ to $52.79 \pm 12.36 \mathrm{nmol} / \mathrm{g}$ tissue. Besides that, intubated of neonatal rat pups with 50 and $100 \mathrm{mg} / \mathrm{kg}$ of aqueous root extract for 30 days also showed improvement retention of passive avoidance and spatial learning tests which increased the percentage of the correct response (Rai et al., 2001).

CT root extract was believed to have permanent changes in the brain which is strongly related to the improvement of learning abilities (Rai et al., 2002). This extract also induced the increasing of dendritic arborization in the brain structure namely hippocampal neurons and amygdala which leads increasing of protein synthesis such as acetylcholinesterase (Rai et al., 2001). In addition, the aqueous root extract was also boost the synthesis of neurotransmitter such as acetylcholine which is a good memory enhancer and learning abilities similar to synthetic drugs such as Nefiracetam (Van der Schyf et al., 2006), dehydroepiandrosterone sulfate (Moore et al. 1995) and FG7142 (Rhodes et al., 1996).

\section{Conclusion}

Clitoria ternatea or telang tree is found to possess a significant number of advantages and natural properties against several diseases and ailments in the human body. Based on this review, it is hoped that the telang tree can be cultivated as one of the leading crops in the world that will be accepted by medical practitioners due to its natural properties and effectiveness in combating several well-known diseases and ailments.

\section{Conflict of Interest}

We declare that we have no conflict of interest.

\section{Acknowledgement}

This study was financially supported by Fundamental Research Grant Scheme (FRGS) with grant number 203/PTEKIND/6711526 obtained from Ministry of Higher Education Malaysia (MOHE).

\section{References}

Anand, P., Doss, A. and Nandagopalan, V. (2011). Antibacterial Studies on Leaves of Clitoria ternatea Linn. A High Potential Medicinal Plant. International Journal of Applied Biology and Pharmacy, 2(3),454-456.

Athnasiadou, S., Kyriazakis, I., Jackson, F. and Coop, R.L. (2001). Direct antihelmintic effects of condensed tannins towards different gastrointestinal nematodes of sheep: In vitro and vivo studies. Veterinary Parasitology, 99(3), 205-219. https:// doi.org/10.1016/S0304-4017(01)00467-8

Barbour, E.K, Al-Sharif, M., Sagherian, V.K., Habre, A.N., Talhouk, R.S. and Talhouk, S.N. (2004). Screening of selected indigenous plants of Lebanon for antimicrobial activity. Journal of Ethnopharmacology, 93(1), 1-7. https:// doi.org/10.1016/j.jep.2004.02.027

Chandrashekhar, C.H., Latha, K.P., Vagdevi, H.M. and Vaidya, V.P. (2007). Antihelminthic activity of the crude extracts of Ficus racemosa. International Journal of Green Pharmacy, 2(2), 100-103

Chauhan, N., Rajvaidhya, S. and Dubey, B.K. (2012). Antiasthmatic Effect of Roots of Clitoria ternatea Linn. International Journal of Pharmaceutical Sciences Research, 3(4), 1076-1079.

Codex Alimentarius Commission. (1995). Codex general standard for contaminants and toxins in food and feed. Codex Stan 193. Retrieved on February 16, 2016 from CODEX website:https:// www.CodexAlimentariusCommission/1995.doc.

Cook, B.G., Pengelly, B.C., Brown, S.D., Donnelly, J.L., Eagles, D.A., Franco, M.A., Hanson, J., Mullen, B. F., Partridge, I.J., Peters, M. and Schultze-Kraft, R. (2005). Tropical forages: An interactive selection tool. Web Tool: http://hdl.handle.net/10568/49072. Brisbane, Australia: CSIRO, DPI\&F(Q1d), CIAT and ILRI.

Daisy, P., Santosh, K. and Rajathi, M. (2009). Antihyperglycemic and antihyperlipidemic effects of Clitoria ternatea Linn in alloxan-induced diabetic rats. African Journal of Microbiology Research, 3 
(5), 287-291.

Deshmukh, S. and Jadhav, V. (2014). Bromatological and mineral assessment of Clitoria ternatea Linn leaves. International Journal of Pharmacy and Pharmaceutical Sciences, 6(3), 244-246

Duhard, V., Garnier, J.C. and Megard, D. (1997). Comparison of the stability of selected anthocyanin colorants in drink model system. Agro Food Industry Hi-Tech, 8(1), 28-34.

Food Standards Australia New Zealand (FSANZ). (2003). The 20th Australian Total Diet Study. Food Standards Australia and New Zealand. Retrieved on February 19, 2016 from FSANZ website: https:// www.foodstandards.gov.au/publications/documents/ FSANZ.

Forbes, G.B. (2012). Human body composition: growth, aging, nutrition, and activity. New York: Springer.

Gomez, S.M. and Kalamani, A. (2003). Butterfly pea (Clitoria ternatea): A nutritive multipurpose forage legume for the tropics - an overview. Journal of Nutrition, 2(6), 374-379.

Gunjan, M., Ravindran, M., Sengamalam, R., Goutam, K.J. and Jha, A.K. (2010). Pharmacognostic and antidiabetic study of Clitoria ternatea. Phytomedicine, 2(4), 373-378.

Kalamani, A. and Michael, Gomez, A. (2001). Genetic variability in Clitoria sp. Annals of Agricultural Sciences, 22(2), 423-245.

Kazuma, K., Noda, N. and Suzuki, M. (2003). Malonylated flavonol glycosides from the petals of Clitoria ternatea. Phytochemistry, 62(2), 229-237. https://doi.org/10.1016/S0031-9422(02)00486-7

Khadatkar, S.N, Manwar, J.V and Bhajipale, N.S. (2008). In-vitro anthelmintic activity of root of Clitoria ternatea Linn. Pharmacognosy Magazine, 4 (13), 148-150.

Mazza, G. and Miniati, E. (1993). Anthocyanins in fruits, vegetables and grains. USA: CRC Press.

Moore, H., Stuckman, S., Sarter, M. and Bruno, J.P. (1995). Stimulation of cortical acetylcholine efflux by FG 7142 measured with repeated microdialysis sampling. Synapse, 21(4), 324-331. https:// doi.org/10.1002/syn.890210407

Mukherjee, P.K., Kumar, V., Kumar, N.S. and Heinrich, M. (2008). The ayurvedic medicine Clitoria ternatea from traditional use to scientific assessment. Journal of Ethanopharmacology, 120(3), 291-301. https:// doi.org/10.1016/j.jep.2008.09.009

National standard of China on Maximum Levels of Contaminants in Foods (NSCMLCF). (2005). USDA Foreign Agricultural Service. Retrieved on February 19, 2016 from USDA website http:// www.fas.usda.gov/gainfiles/200608/146208660.doc.

Neda, G.D., Rabeta, M.S. and Ong, M.T. (2013). Chemical composition and anti-proliferative properties of flowers of Clitoria ternatea. International Food Research Journal, 20(3), 12291234.

Nithianantham, K., Shyamala, M., Chen, Y., Latha, L.Y., Jothy, S.L. and Sasidharan, S. (2011). Hepatoprotective potential of Clitoria ternatea leaf extract against paracetamol induced damage in mice. Molecules, 16(12), 10134-10145. https:// doi.org/10.3390/molecules161210134

Nithianantham, K., Ping, K.Y., Latha, L.Y., Jothy, S.L., Darah, I., Chen, Y., Chew, A.L. and Sasidharan, S. (2013). Evaluation of hepatoprotective effect of methanolic extract of Clitoria ternatea (Linn.) flower against acetaminophen-induced liver damage. Asian Pacific Journal of Tropical Disease, 3(4), 314319. https://doi.org/10.1016/S2222-1808(13)60075-4

Patras, A., Brunton, N.P., O'Donnell, C., and Tiwari, B.K. (2010). Effect of thermal processing on anthocyanin stability in foods, mechanisms and kinetics of degradation. Trends in Food Science and Technology, 21(1), 3-11. https://doi.org/10.1016/ j.tifs.2009.07.004

Rabeta, M.S. and An Nabil, Z. (2013). Total phenolics compounds and scavenging activity in Clitoria ternatea and Vitex negundo Linn. International Food Research Journal, 20(1), 495-500.

Rai, K.S., Murthy, K.D. and Rao, M.S. (2001). Clitoria ternatea (Linn) root extract treatment during growth spurt period enhances learning and memory in rats. Indian Journal of Physiology and Pharmacolology, 45(3), 305-313.

Rai, K.S., Murthy, K.D., Karanth, K.S. and Rao, M.S. (2002). Clitoria ternatea root extract enhances acetylcholine content in rat hippocampus. Fitoterapia, 73(7), 685-689. https://doi.org/10.1016/ S0367-326X(02)00249-6

Ramaswamy, V., Varghese, N. and Simon, A. (2011). An investigation on cytotoxic and antioxidant properties of Clitoria ternatea. International Journal Drug Discovery, 3(1), 74-77. https:// doi.org/10.9735/0975-4423.3.1.74-77

Rhodes, M.E., Li, P.K., Flood, J.F. and Johnson, D.A. (1996). Enhancement of hippocampal acetylcholine release by the neurosteroid dehydroepiandrosterone sulfate: an in vivo microdialysis study. Brain Research, 733(2), 284-286. https:// doi.org/10.1016/0006-8993(96)00751-2

Salhan, M., Kumar, B., Tiwari, P., Sharma, P., Sandhar, H.K. and Gautam, M. (2011). Comparative 
anthelmintic activity of aqueous and ethanolic leaf extracts of Clitoria ternatea. International Journal of Drug Development Research, 3(1), 62-69.

Sarojini, N., Chandra Kanti, C., Dibya Singh Das, M., Priyanka, J. and Usha Kumari, S. (2012). Antihelmintic activity of Clitoria ternatea leaf extracts. Journal of Patient-Reported Outcomes, 2 (6), 49-50.

Shanmugasundram, R., Devi, V.K., Tresina, P.S., Maruthupandian, A. and Mohan, V.R. (2010). Hepatoprotective activity of ethanol extract of Clitoria ternatea Linn and Cassia angustofolia vahl leafs against $\mathrm{CCl} 4$ induced liver toxicity in rats. International Research Journal of Pharmacy, 1(1), 201-205.

Shekhawat, N. and Vijayvergia, R. (2010). Evaluation of antimicrobial potential of some medicinal plants against plant and human pathogens. Journal of Pharmaceutical Research, 3, 700-702.

Slimestad, R., Anderson, O.M., Francis, G.W., Martson, A. and Hostettmann, K. (1995). Syringetin 3-O-(6"acetyl)- $\beta$-glucopyranoside and other flavonols from needles of Norway spruce, Picea abies. Phytochemistry, 40(5), 1537-1542. https:// doi.org/10.1016/0031-9422(95)00383-I

Taur, D.J. and Patil, R.Y. (2011). Evaluation of antiasthmatic activity of Clitoria ternatea L. roots. Journal of Ethnopharmacology, 136(2), 374-376. https://doi.org/10.1016/j.jep.2011.04.064

Thompson, D.P. and Geary, T.G. (1995). The structure and function of helminth surfaces. USA: Academic Press Ltd. https://doi.org/10.1016/B978-0124733459/50013-1

Van der Schyf, C.J., Geldenhuys, W.J. and Youdim, M.B. (2006). Multifunctional neuroprotective drugs for the treatment of cognitive and movement impairment disorders, including Alzheimer's and Parkinson's disease. Drugs Future, 31, 447-460. https://doi.org/10.1358/dof.2006.031.05.985904 